\title{
THE EFFECTIVENESS OF EUROPEAN UNION LAW IN POLAND. THE EXAMPLE OF LABOUR LAW
}

\author{
Monika Tomaszewska, Sylwia Majkowska-Szulc*
}

\section{The concept of effectiveness in European Union law}

Effectiveness in fields such as combating discrimination based on sex, racial or ethnic origin, religion or belief, disability, age or sexual orientation, collective redundancies, transfer of undertakings and almost all of labour law (except for the free movement of workers) means achieving a certain degree of legal harmonisation among the legal systems of the European Union and its Member States. This depends to a large degree on the adoption and implementation of directives, since the sphere of labour law is primarily governed by directives. Pursuant to Article 288 of the Treaty on the Functioning of the European Union ${ }^{1}$ (ex Article 249 of EC Treaty) the Member States are obliged to achieve the objective(s) laid down by the relevant directive(s). This obligation means, as the European Court of Justice held in the case of Von Colson and Kamann that Member States are obliged to adopt "within the framework of their

* University of Gdańsk.

1 Consolidated Version of the Treaty on the Functioning of the European Union, O. J. 30.3.2010, C 83, p. 47. 
national systems, all the measures necessary to ensure that the directive is fully effective in accordance with the objective which it pursues" ${ }^{2}$. It is therefore necessary, in order to implement directives, to examine which requirements Member States ought to provide in their legal systems and what are legal consequences or sanctions to be faced in the event of failing to implement a directive's objectives ${ }^{3}$. Granting that effect means that Member States' obligation arising from a directive:

"to achieve the result envisaged by that directive and their duty to take all appropriate measures, whether general or particular ${ }^{4}$, to ensure the fulfilment of that obligation are binding on all the authorities of the Member States including, for matters within their jurisdiction, the courts etc" ${ }^{\text {"5 }}$.

The role of effectiveness in the European Union legal order is certainly more extensive and is not merely limited to directives. It has, through the jurisprudence of the European Court of Justice, acquired the status of a general principle of $\mathrm{EU} \mathrm{law}^{6}$ which has played an important part in delineating the functioning and coherence of, initially, the European Community and now the European Union. Effectiveness is a precondition and foundation for any legal system ${ }^{7}$ but in case of the EU legal order it depends upon the effective implementation of their obligations by the Member States. Accordingly, there is a direct link between the discharge

2 Von Colson and Kamann v. Land Nordrhein Westfalen, Case no 14/83, Judgement of 10.4.1984, ECR 1984, p. 1891, at para. 15 (hereinafter as Von Colson).

3 Von Colson, para 16.

4 Article 4(2)(2) Treaty on the Functioning of the European Union.

5 See Von Colson, par. 26; Marleasing SA v La Comercial Internacional de Alimentacion SA, Case no C-106/89, Judgement of 13.11.1990, ECR 1990, p. I-4135, at para 8; Paola Faccini Dori v Recreb Srl., Case no C-91/92, Judgement of 14.7.1994, ECR 1994, p. I-03325, at para 26; Bernhard Pfeiffer et al. v Deutsches Rotes Kreuz, Kreisverband Waldshut eV, joined cases no C-397/01 to C-403/01, Judgement of 5.10.2004, ECR 2004, p. I-08835, at para 110 and Kiriaki Angelidaki and Others v Organismos Nomarchiakis Autodioikisis Rethymnis, Charikleia Giannoudi v Dimos Geropotamou and Georgios Karabousanos and Sofoklis Michopoulos v Dimos Geropotamou, joined Cases no C-378/07 to C-380/07, Judgement of 23.4.2009, ECR 2009, p. I-03071, at para 106.

6 Scott SA and Kimberly Clark SAS v Ville d'Orléans, Case no C-210/09, Judgement of 20.5.2010, not published in ECR 2010, p. I-04613, at para. 21.

7 M. Accetto, St. Zleptnig, The Principle of Effectiveness: Rethinking Its Role in Community Law, European Public Law 2005, Vol. 11, No. 3, at p. 375. 
of obligations arising from the Treaty (and other legal instruments) by Member States and the aforementioned general principle. The doctrine emphasises a close connection between the full and uniform application of law, European integration and effectiveness. To date, European Union law has been treated as the basic and most important instrument of European integration between the European Union and its Member States and effectiveness has been considered to be a fundamental element of EU law. European integration implies the connection of two legal systems and obliges Member States to ensure that "individual Community rights be practicable and enforceable at the domestic level". EU law, especially in the field of labour law, performs two basic functions: (1) economic connection with the Internal Market and (2) protecting the weaker party in an employment relationship ${ }^{8}$. Ensuring the effectiveness of labour rights defined by EU law in national law has positive implications for individuals and the whole European Union system.

\section{The principle of effectiveness as a general principle of European Union law}

In the absence of express reference in the treaty provisions to the principle of effectiveness, the Court of Justice recognizes its origins from Article 4(3) TEU (ex Article 10 of EC Treaty). It is possible to identify two aspects of European Union law effectiveness: substantive and procedural. From the perspective of the latter, it is important to assess whether Polish legal provisions governing the protection of individuals' rights, including the rights of employees, render it practically impossible, or excessively difficult, to exercise the rights conferred by EU law, and particularly those conferred by EU directives. Moreover, the effectiveness of EU law constitutes a rule of interpretation which requires courts to interpret legislation in such a way as to ensure that it best achieves the objectives set out by EU law'. This applies not only to the Court of Justice but also

8 See O.O. Cherednychenko, Fundamental Rights, Contract Law and the Protection of the Weaker Party. A Comparative Analysis of the Constitutionalisation of Contract Law, with Emphasis on Risky Financial Transactions, Wolters Kluwer, Utrecht 2007.

9 S. Biernat, Zasada efektywności praw wspólnotowego w orzecznictwie Europejskiego Trybunału Sprawiedliwości [in:] S. Biernat (ed.), 'Studia z prawa Unii Europejskiej w piątą 
to national courts ${ }^{10}$, especially insofar as ensuring the effectiveness of national law measures adopted pursuant to directives ${ }^{11}$. The concept of EU law effectiveness has evolved alongside the continuing development of the EU legal system itself and remains subject to rapid changes.

Other principles of EU law application, such as the supremacy or direct effect of European law, also contribute to ensuring the effectiveness of EU law in national legal orders but do not sufficiently guarantee its effectiveness ${ }^{12}$. As regards non directly applicable provisions, the principle of indirect effect or sympathetic interpretation is also helpful. It applies in particular in the event of incomplete implementation or failure to observe the time limits laid down for implementation of directives. However, subsequently the Court of Justice extended the obligation to interpret national law measures in light of the wording and purpose of EU law as a whole and not merely directives ${ }^{13}$.

Member States may deprive EU legislation of its effectiveness in various ways. The most apparent violations by Member States are the complete failure to implement, or only partial implementation of, directives and other EU law instruments. In the opinion of M. Accetto and S. Zleptnig effectiveness may also be eroded by, for example:

"specific substantive and procedural hurdles at the national level that are not immediately apparent: subtle procedural rules, administrative practices adopted by national authorities, or systemic failures in the institutional

rocznicę Katedry Prawa Europejskiego Uniwersytetu Jagiellońskiego', Wyd. UJ, Kraków 2000, at pp. 61-71. See, to that effect A. Wyrozumska, Zasady dziatania Unii Europejskiej (zasada efektywności) [in:] J. Barcz, M. Górka, A. Wyrozumska, 'Instytucje i prawo Unii Europejskiej. Podręcznik dla kierunków zarządzania i administracji', LexisNexis, Warszawa 2008, at p. 90.

10 See D. Miąsik, Zasada efektywności [in:] A. Wróbel (ed.), 'Stosowanie prawa Unii Europejskiej przez sądy', Kantor Wydawniczy Zakamycze, Kraków 2005, at p. 318.

11 See for example Von Colson.

12 K. Kowalik, Zasada efektywności [in:] A. Wróbel, Szwarc-Kuczer, K. Kowalik (eds), 'Stosowanie prawa Unii Europejskiej przez sądy, M. Tom II, Zasady - Orzecznictwo - Piśmiennictwo', Wolters Kluwer Polska, Warszawa 2007, at p. 272.

13 S. Biernat, Wykładnia prawa krajowego zgodnie z prawem Wspólnot Europejskich [in:] C. Mik (ed.), 'Implementacja prawa Wspólnot Europejskich w krajowych porządkach prawnych', TNOiK, Torun 1998, at p. 123 et seq. 
set-up of authorities in charge of ensuring the proper application of Community law"14.

This interpretation is based upon Article 4(3) of the EU Treaty (ex Article 10 EC Treaty) which obliges Member States to take any appropriate measure, general or particular, to ensure fulfilment of the obligations arising out of the Treaties or resulting from the acts of the institutions of the Union. Any appropriate measure means any provision of a national legal system and any legislative, administrative ${ }^{15}$ or judicial practice ${ }^{16}$. The scope of the principle of effectiveness covers legal provisions, independent regulations ${ }^{17}$ proclaimed by, for instance, regional authorities ${ }^{18}$, constitutionally independent authorities responsible for the maintenance of public order and safety ${ }^{19}$, public authorities providing public health services ${ }^{20}$ etc. if they are capable of impairing the effectiveness of EU law ${ }^{21}$. This general principle would be seriously hampered if national practices were permitted to remain unaffected, so its scope also includes the practice of national, public and even private ${ }^{22}$, institutions responsible for ensuring the proper application of EU law. The scope of the principle of effectiveness includes - but is not limited to - implementation, enforcement, impact and compliance. ${ }^{23}$

14 Supra note 7, at p. 376.

15 The Queen v. Secretary of State for Transport, ex parte: Factortame Ltd and others, Case no C-213/89, Judgement of 19.6.1990, ECR 1990, p. I-2433, at para 20 (hereinafter as Factortame).

16 Factortame, at para 22.

17 A. Foster and others v British Gas plc, Case no C-188/89, Judgement of 12.7.1990, ECR 1990, p. I-3313, at para 22 (hereinafter as Foster).

18 Fratelli Costanzo v Comune di Milano, Case no 103/88, Judgement of 22.6.1989, ECR 1989, p. 1839.

19 Johnston v Chief Constable of the Royal Ulster Constabulary, Case no 222/84, Judgement of 15.5.1986, ECR 1986, p. 1651.

20 M. H. Marshall v Southampton and South-West Hampshire Area Health Authority (Teaching), Case no 152/84, Judgement of 26.2.1986, ECR 1986, p. 00723, at para 49.

21 Factortame, para 20.

22 Foster, para 22.

23 F. Snyder, The Effectiveness of European Community Law: Institutions, Processes, Tools and Technique, The Modern Law Review 1993, Vol. 56, No. 1, at p. 19; C. Mik, Europejskie prawo wspólnotowe. Zagadnienia teorii i praktyki, C.H. Beck, Warszawa 2000, at p. 554. 


\section{Legal consequences of the principle of effectiveness}

Legal consequences of the principle of effectiveness should be regarded as the process for implementing changes aimed at formal and practical implementation of European Union legislation, rather than as a single action performed by the principal national legislative authorities. The overwhelming majority of legal academics and commentators identify two main aspects of the principle of effectiveness: a positive aspect associated with the order of effective implementation of EU legislation and a negative aspect generally taking the form of a prohibition on questioning the validity (binding force) of EU legislation. Transformation of the legal system, within that context, refers to aspects of both material and procedural law. According to $C$. Mik coping with these duties requires changes which would affect the very organization of public authorities apparatus, its operation procedures and powers as well as changes relating to the functioning of the legal system, such as the legislative procedure, application and monitoring the compliance of domestic legislation with EU law ${ }^{24}$.

Polish labour law adopts an extensive meaning to the term "labour law provisions" and, pursuant to Article 9 of the Polish Labour Code, the national legislator applies this term to define the provisions of the labour code itself as well as provisions of other acts and secondary legislation defining the rights and obligations of employees and employers, together with provisions of collective labour agreements and other collective arrangements, rules based on the statutory law and specifying the rights and duties of the parties to an employment relationship. The Polish law concept of labour law extends to cover not only universally binding legislation but also arrangements ${ }^{25}$ (agreements ${ }^{26}$ ) or unilateral

24 C. Mik, op. cit., at p. 553.

25 Case no II PK 137/09, Judgment of the Polish Supreme Court of 25.11.2009, Monitor Prawa Pracy, 2010/7/368.

26 Case no III KAS 2/08, decision of the Polish Supreme Court of 21.10.2008, OSNP 2009/7-8/111; See also T. Chauvin, Umowy prawotwórcze jako umowy prawa publicznego, Kwartalnik Prawa Publicznego 2003, Vol. 2, at p. 7. 
acts $^{27}$ possessing normative character ${ }^{28}$. In legal nomenclature the latter category of legislation is defined as a specific ${ }^{29}$ (autonomous ${ }^{30}$ ) source of labour law, covered by substantive labour law ${ }^{31}$. Accordingly, the legal consequences of the principle of effectiveness are apt to be extended to the operations of social partners (i.e. employers, trade unions and other forms of labour representation), since they have been entrusted with rule-making competences associated with the right to regulate the legal situation of individuals collectively ${ }^{32}$. The legal authorisation for such rule-making competences impacts upon the effectiveness of European law, irrespective of whether such impact is categorised as direct or indirect, assuming the subsequent nature of powers granted to social partners as compared with the national legislature. Consequently, it should be accepted that the changes brought about by the effective implementation of EU law shall cover not only the organization of national authorities but also the organization, operational procedure and scope of powers

27 See Case no III PK 17/08, Judgment of the Polish Supreme Court of 4.9.2008, OSNP 2010/1-2/12.

28 See L. Kaczyński, Charakter prawny układów zbiorowych pracy, Państwo i Prawo 1996, Vol. 7, at p. 25; G. Goździewicz, Regulamin pracy w znowelizowanym kodeksie pracy, Prawo Pracy 1996, Vol. 6, at p. 19; A. Jedliński, Statut jako źródło prawa pracy, Państwo i Prawo 1999, Vol. 4, at p. 28; Z. Niedbała, O niektórych kontrowersjach wokót porozumień zbiorowych jako źródeł prawa pracy, Gdańskie Studia Prawnicze 2007, Vol. XVII, No. 2, at p. 165; U. Jackowiak, komentarz do art. 9 KP [in:] U. Jackowiak (ed.), M. Piankowski, J. Stelina, W. Uziak, A. Wypych-Żywicka, M. Zieleniecki, 'Kodeks pracy z komentarzem', wyd. IV, Gdańsk 2004; See also M. Bednarski, J. Wratny, Porozumienia socjalne zwiq̨zane z prywatyzacja przedsiębiorstw państwowych - fenomen społeczny i prawny, Warszawa 2000.

29 K.W. Baran, Zbiorowe prawo pracy, wyd. UNIVERSITAS, Kraków 2002, p. 43 et seq.; K.W. Baran, B.M. Ćwiertniak, D. Dorre-Nowak, K. Walczak, Prawo pracy, Warszawa 2009, p. 88 et seq.; M. Włodarczyk, "Swoiste" źródła prawa pracy - kilka uwag na temat ich genezy i funkcji [in:] Z. Góral (ed.), 'Z zagadnień współczesnego prawa pracy - Księga jubileuszowa Profesora Henryka Lewandowskiego', Warszawa 2009, at pp. 107-117.

30 L. Florek, Autonomiczne (pozaustawowe) źródła prawa pracy [in:] B. von Maydell, T. Zieliński (eds.), 'Ład społeczny w Polsce i w Niemczech na tle jednoczącej się Europy. Księga pamiątkowa poświęcona Czesławowi Jackowiakowi', Warszawa 1999, at pp. 48-65.

31 See Case no I PK 6/09, Judgement of the Polish Supreme Court of 5.5.2009, available at LEX database.

32 Union royale belge des sociétés de football association ASBL v Jean-Marc Bosman, Royal club liégeois SA v Jean-Marc Bosman and others and Union des associations européennes de football (UEFA) v Jean-Marc Bosman, Case no C-415/93, Judgement of 15.12.1995, ECR p. I-04921. 
of social partners. It should be noted that their main role is envisaged in the legislative process as well as in collective bargaining agreements and concluding other types of collective agreements, if they are based on lex specialis.

Settled case law of the European Court of Justice, and in particular the criteria laid down in the Foster case $\mathrm{e}^{33}$, support this view. In accordance with the guidelines provided by the Court, the contractual provisions of social partners may be included in the scope of legal provisions referred to in Article 4(3) of TEU provided that the instrument authorizing their actions derives from public law. However, when developing that thesis the Court of Justice limited the scope of consequences of the principle of effectiveness by the requirement of attributing the contractual provisions to social and political decisions, which reflect the guidelines developed by public authorities of Member States ${ }^{34}$. Where the aforementioned criteria are fulfilled, the responsibility of social partners for ensuring the effectiveness of EU law is comparable to that of a Member State itself.

However, it is possible to notice a trend in recent jurisprudence towards extending the scope of monitoring compliance of national law with EU legislation so as to include individuals i.e. parties whose legal status is not State-related. The starting point in the present situation is Article 20 of TFEU which recognizes the legal capacity of individuals (an individual is subject to rights and obligations under the Treaty ${ }^{35}$ ) as well as the correct assumption that the actions or omissions of individuals may in fact weaken or undermine obligations arising under EU law. Taking into account the specificity and purpose of labour legislation, which aims principally to create mechanisms designed to ensure employee protection because of their weaker position in relations with their employer, the practical implementation and discharge of such obligations acquire special significance. Conversely, the form adopted by European Union labour legislation, wherein the rights and obligations of the parties to the labour relationship are to an overwhelming extent governed by directives, means that the most apparent reforms concern procedures for

33 Foster, at para. 22.

34 Subject to the criteria developed by the Court in Foster, at para. 22.

35 Article 20 paragraph 2 TFEU has the following wording: "Citizens of the Union shall enjoy the rights and be subject to the duties provided for in the Treaties [...]". 
the application of law. In this respect two essential theories rooted in the principle of loyal cooperation and the principle of effectiveness should be emphasised, namely the doctrine of direct effect and the indirect effect of EU legislation.

\section{Functioning of the principle of effectiveness in Poland}

\subsection{The case of Mr. Czesław Miś}

The effectiveness of European Union law in Poland was subjected to a difficult test in relation to cases concerning the working time of medical doctors. The incompatibility of Polish regulations governing working time of medical workers with EU standards was brought to the attention of the general public by virtue of legal proceedings known as the Miś Case. On 22 November 2004 the District Court in Nowy Sącz, IV Labour Department issued a judgement in which it dismissed the claim lodged by Dr C. Miś in which the claimant sought a court's order granting rest time to compensate for work performed in excess of working time standards covering the period from 1.5.2004 to 30.9.2004. The Court's dismissal of the claim stated that EU directives were incapable of application to relations between an employee and a public employer, in this case the hospital. Moreover, according to the Court, the period for implementation of the aforementioned directives had not yet expired. In essence, the judge's insufficient knowledge of European Union law rendered it impossible for the employee to exercise the rights conferred by the working time directive, thereby failing to ensure the effectiveness of directives. Accordingly, the claimant appealed to The Regional Court in Kraków, VI Labour Department. The appeal was also dismissed. Consequently, the employee was again deprived of his rights under the EU directives, rendering the provisions thereof ineffective within Poland.

Dr. C. Miś lodged a cassation appeal against that ruling, in consequence of which the the Supreme Court, in a judgement of 6.7.2006, set aside the judgement of The Regional Court in Kraków and referred the case back for a re-hearing. Sąd Najwyższy (the Supreme Court) emphasized the requirement to ensure compliance with EU law and emphasised the principle of supremacy of EU law over national law. However, The Supreme Court raised some doubts as to the interpretation of, inter alia, employees' 
rights to equivalent periods of compensatory rest. Although the Supreme Court enabled the claimant to exercise his rights under the directive, these interpretation doubts also placed some practical limits on the effectiveness of the working time directive. Generally speaking, given the existence of doubts as to the interpretation or application of potentially protective measures for employees in the event of the national law's incompatibility with the provisions of the directive, it seemed justified and useful for the Supreme Court to refer a question to the Court of Justice for a preliminary ruling. Nevertheless, no such reference was made. However, subsequently it transpired that the Supreme Court, in a number of cases, was required to search for protective remedies available to employees within the Polish legal order in the event of an infringement of the provisions of the working time directive.

On 29.12.2006 the Regional Court in Kraków allowed an appeal against a first instance judgment ordering a hospital to grant to the claimant compensatory rest time. Consequently, as a result of the direct application of the provisions of directives $93 / 104^{36}$ and $2003 / 88^{37}$, the court held that time of medical duty is working time. The court accepted that the defendant employer's organisation of working time rendered it impossible for the claimant to take advantage of a day and week rest standards provided for in the Directive. Accordingly, this ruling enabled the employee to exercise his rights under directives effectively. This case affected the Polish statute on health care institutions (ustawa o zakładach opieki zdrowotnej) which was amended on 1.1.2008. It stated, inter alia that time of medical duty is included in working time in its entirety. To that extent, the statute is now consistent with directive 2003/88.

In more developed countries, employment directions and preferences concerning working time depend upon the situation on the labour market. The Miś Case demonstrates that the situation on the Polish labour market is often governed by its own specific rules. Physicians working at Polish public health care institutions generally consider their remuneration to

36 Council Directive 93/104/EC of 23 November 1993 concerning certain aspects of the organization of working time, O. J. 13.12.1993, L 307, at p. 18.

37 Directive 2003/88/EC of the European Parliament and of the Council of 4 November 2003 concerning certain aspects of the organisation of working time, O. J. 18.11.2003, L 299, at p. 9. 
be unsatisfactory which leads to the conclusion that they do not obtain income at a level guaranteeing them an acceptable living standard. However, perhaps it could give the impression that they tend to prefer rest time to additional hours of overtime work.

\subsection{The case of Ms. Halina Nerkowska}

On 22.5.2008 the European Court of Justice handed down judgement in case C-499/06 Halina Nerkowska v. Zakład Ubezpieczeń Społecznych, Oddziat $w$ Koszalinie (ZUS) regarding the latter's refusal to pay a disability pension on the ground that the claimant did not reside in Polish territory. The benefit in issue concerned the claimant's entitlement, previously established, to a pension resulting from a partial incapacity to work, linked to her stay in places of isolation. Although ZUS did not query the claimant's entitlement to the benefit per se, it refused to pay it on the sole ground that she did not reside in the territory of the Republic of Poland. According to the claimant the decision of ZUS was contrary to Article 21 TFEU (ex Article 18 of EC Treaty).

The European Court of Justice ruled that Article 21 TFEU (ex Article 18(1) of EC Treaty) is to be interpreted as precluding Polish legislation under which it refuses, generally and in all circumstances, to pay to its nationals a benefit granted to civilian victims of war or repression solely because they are not resident in the territory of Poland throughout the period of payment of the benefit, but in the territory of another Member State (Germany).

The national proceedings in relation to which this preliminary reference was made, and in which the judgement of the European Court of Justice was subsequently applied, evidence the manner in which the interpretation of national law has altered by virtue of the influence of EU law. It serves as an example illustrating how national authorities, including the Polish courts, have interpreted national legislation consistently with EU law. The irrevocable consequence of integration of the Polish legal system with the European Union legal order is the application of EU law for the benefit of individuals who apply to the national authorities claiming enforcement of their rights under $\mathrm{EU} \mathrm{law}^{38}$.

38 On the role of national public administration authorities in relation to the European Union membership see: M. J. Ziller, Les administrations doivent faire face à l'élargissement 


\subsection{The case concerning Polish shipyard workers}

The Act on special rules governing the termination of an employment relationship for reasons not attributable to employees ${ }^{39}$ (collective redundancies act) implements in the scope of its regulation, the Council Directive No. 98/59/EC ${ }^{40}$. This is expressly stated in note 1 of the Act. Additionally, Poland advised the European Commission that this Act constitutes the national executive measure adopted for the purposes of implementing this Directive (reference number of the National Execution Measures (MNE(2003)52084). Directive 98/59/EC was adopted pursuant to Article 94 of EC Treaty and has protective function towards employees. In the light of the Treaty of Accession of the Republic of Poland to the European Union ${ }^{41}$, Poland has committed to comply with community law in accordance with the principle of primacy of EU law. Therefore, it is unacceptable to exclude the application of a directive in favour of a national legislative act, including the Act of 19 December 2008 on Compensation Proceedings Regarding the Entities of Special Importance for the Polish Shipbuilding Industry, the so-called Compensation Act ${ }^{42}$. In view of the national court's doubts concerning the application of the Act on termination of an employment relationship for reasons not attributable to employees, former employees of the Gdynia Shipyard SA requested that the court interpret the provisions of this Act so as to ensure their consistency with EU law and, more particularly, in the light of Directive 98/59/CE on collective redundancies ${ }^{43}$. The Polish legislator adopting the Act on collective redundancies within the scope of discretion permitted by Directive 98/59/EC, which enables more favourable measures and established severance pay. However in doing so, it operated within the scope of the implementation procedure. Accordingly, that is the measure

et à l'approfondissement de l'intégration européenne - avec ou sans traité constitutionnel, Revue Française d’Administration Publique 2005, Vol. 114 "L'européanisation des administrations: nouvelles missions, nouveaux partenaires", at p. 213 et seq.

39 Polish O. J. 2003, No. 90, heading 844.

40 Council directive 98/59/EC of 20.7.1998 on the approximation of the laws of the Member States relating to collective redundancies, O. J. 12.8.1998, L 225, p. 16.

41 O. J. 21.6.2005, L 236, at p. 17.

42 Polish O. J. 2008, No. 233, heading 1569, p. 1.

43 Supra note 40. 
which is subject to evaluation in terms of the purposes of the Directive. Pursuant to Article 288 TFEU (ex Article 249 of EC Treaty) a directive shall be binding, as to the result to be achieved, upon each Member State to which it is addressed, but shall leave to the national authorities the choice of form and methods. The Polish legislator decided to adopt a measure in the form of severance pay. The principle of effectiveness of EU law precludes a situation in which exercising the rights granted by a directive before national courts is impossible or excessively difficult. In accordance with the Directive the Member States should ensure that workers' representatives and/or workers have at their disposal administrative and/or judicial procedures in order to ensure that the obligations laid down in Directive 98/59/EC are fulfilled (recital 12 of the preamble to the Directive 98/59/EC). The Polish legislator intentionally excluded employees' right to severance pay by virtue of the Compensation Act, since by doing so it would create a legal provision inconsistent with EU law. Nevertheless, Polish courts of first and second instance in Gdynia, Gdańsk and Szczecin have negated the effectiveness of Directive 98/59/EC of 20.7.1998. In fact, the continued reluctance of the Polish courts to apply EU law is often a consequence of their insufficient knowledge of EU law. Perhaps notifying the European Commission on that issue would help to resolve this problem as, in fact, the liquidation of shipyards in Gdynia and Szczecin arose as a consequence of the European Commission's decision on repayment of State aid granted to those shipyards. An alternative solution would be for one of the Polish courts to refer a question to the Court of Justice for a preliminary ruling.

\section{Changes in the organizational structure and scope of competences of state authorities apparatus carrying out labour law tasks}

As mentioned above, organizational changes cover first of all transpositions relating to organization of the state authorities apparatus. Transformations resulting from coordination of social security systems have not been mentioned in this paper, as this sphere exceeds the rationae materiae of labour law and its subject-matter is covered by another branch of law, namely the social security system. 
As far as public institutions are concerned, one may witness a change to the legal status of public administration bodies (governmental or self-governmental) which are entitled to provide information on employment conditions within the territory of Poland or were created for the purpose of exercising supervisory and control functions concerning the fulfilment of such conditions. For example, public employment services (in the form of district and provincial employment offices) under the Accession Treaty were identified as liaison institutions. An additional function of those offices relates to the process of creating the EU internal market and ensuring an effective implementation of personal freedoms, including first of all the free movement of workers and freedom to provide services, international, interregional and cross-border exchange of job vacancies and applications for employment. In such circumstances it is necessary to develop a legal basis to identify the detailed conditions for conducting, by public employment services, employment agency services, EURES $^{44}$ services, employment consultancy and employment information, organization of trainings and assistance in active employment searching. Statutory reforms were implemented by the adoption in 2004 of a new act on employment promotion and labour market institutions ${ }^{45}$ as well as secondary legislation adopted pursuant to this statute which governs the detailed conditions for providing labour market services by public employment services ${ }^{46}$. The practical exercise of the supervision required in order to ensure the effective completion of tasks entrusted to competent and liaison institutions necessitated a reorganization of the Ministry of Labour and Social Policy, which was nota bene also considered

44 Article 21 of Council Regulation (EEC) No. 1612/68 on freedom of movement of workers within the Community, O. J. 19.12.1968, L 257, at p. 2 et seq. and Commission Decision 2003/8/EC of 23 December 2002 implementing Council Regulation (EEC) No. 1612/68 as regards the clearance of vacancies and applications for employment (notified under document number C(2002) 5236) (Text with EEA relevance), O. J. 10.1.2003, L 005, at p. 16; see also EURES Charter 2003/C 106/03.

45 Before accession the Act on Employment and Combating Unemployment was in force, however currently Act on employment promotion and labour market institutions of 20 April 2004 Polish O. J. 2004, is in effect No. 69, heading 415.

46 The Ordinance of the Minister of Labour and Social Policy concerning detailed conditions of providing labour market services by the Public Employment Services of 2 March 2007, Polish O. J. 2007, No. 47, heading 315. 
to be a liaison institution ${ }^{47}$. Accordingly, the employment services of Member States collectively constitute the European Employment and Job Mobility Network EURES.

The status of a liaison institution is also attributed to the National Labour Inspectorate (Państwowa Inspekcja Pracy) which is an authority established in order to supervise and inspect compliance with labour law, in particular occupational health and safety rules and regulations, as well as regulations concerning the legality of employment and other paid work falling within the scope of the Act ${ }^{48}$. The Inspectorate is directly subordinate to the Parliament of the Republic of Poland (i.e. Sejm). Reforms aimed at ensuring the effectiveness of EU law concern, primarily, an extension to the Inspectorate's sphere of competence ${ }^{49}$, since it is now entitled not only to supervise employers' compliance with obligations arising from Polish law but is also obliged to exercise similar supervision as regards compliance with obligations imposed by European Union legislation ${ }^{50}$.

Moreover, the obligations imposed on foreign employers to provide certain information have been extended to include information concerning the minimum terms of employment of employees posted to perform work within the territory of Poland ${ }^{51}$. Information-providing obligations have also been expanded in the case of employers having their registered office in Poland so as to extend to information concerning the terms

47 See Organisational rules of the Ministry of Labour and Social Policy making an appendix to order No. 9 of Minister of Labour and Social Policy of 16 September 2009.

48 See Article 1 of the Act on National Labour Inspectorate of 14.4.2007, Polish O. J., No. 89, heading 589.

49 L. Florek, Zakres kontroli Państwowej Inspekcji Pracy, Praca i Zabezpieczenie Społeczne 2008, Vol. 3, at p. 18.

50 For example, National Labour Inspectorate supervises discharging, by employers, their duties referred to in Article 35 and Article 37 paragraph 5 and paragraph 6 of Regulation (EC) No. 1907/2006 of the European Parliament and of the Council of 18 December 2006 concerning the Registration, Evaluation, Authorisation and Restriction of Chemicals (REACH), establishing a European Chemicals Agency, amending Directive 1999/45/EC and repealing Council Regulation (EEC) No. 793/93 and Commission Regulation (EC) No. 1488/94 as well as Council Directive 76/769/ EEC and Commission Directives 91/155/EEC, 93/67/EEC, 93/105/EC and 2000/21/EC, O. J. 30.12.2006 L 396, p. 1.

51 See Article 10 item 13 of the Act on National Labour Inspectorate. 
of employment of employees posted to perform work in the territory of another European Union Member State ${ }^{52}$. The abovementioned reforms required transformation of the National Labour Inspectorate's organizational structure and led to the establishment of the Legality of Employment Department and the Working Conditions Department ${ }^{53}$. Furthermore, the Act imposed on the National Labour Inspectorate the duty to cooperate with other European Union Member States' authorities competent for the supervision of employment and working conditions ${ }^{54}$ which is a natural corollary of acquiring information concerning employment conditions in other Member States.

\section{Changes to the organisational structure and scope of powers of social partners}

Equally important reforms, arising from the need to ensure the formal and practical implementation of EU obligations, affected social partners. The first group of reforms relates to the right to participate in the procedures referred to in Articles 157-155 TFEU (ex Articles 137-139 of EC Treaty). However, this right is only available to such organisations meeting the conditions specified by the Commission in its Communication of $1993^{55}$, repeated and supplemented by the Commission in subsequent Communications from 1996 and 1998 ${ }^{56}$. Participation in the social dialogue at the European Union level through participation in trade unions structures with an European dimension is dependent upon Polish associations or trade unions fulfilling the representativeness condition, whilst the representativeness criterion enabling participation

52 See Article 10 item 14a ustawy o Państwowej Inspekcji Pracy (Act on National Labour Inspectorate).

53 A. Jasińska-Cichoń, Ustawa o Państwowej Inspekcji Pracy, Warszawa 2008.

54 See Article 10 item 14 ustawy o Państwowej Inspekcji Pracy (Act on National Labour Inspectorate).

55 Communication concerning the application of the Agreement on social policy presented by the Commission to the Council and the European Parliament, COM (93) 600 final.

56 Communication from the Commission adapting and promoting the social dialogue at Community level, COM (98) 322 final. 
in consultations at an EU level is subject to the following conditions developed by the Commission. The consulted organizations should be cross-industry or relate to specific sectors or categories and be organized at European level; consist of organizations which are themselves an integral and recognized part of Member States' social partner structures and with the capacity to negotiate agreements and/or which are representative of a number of Member States, as far as possible; as well as have adequate structures to ensure their effective participation in the consultation process $^{57}$. Membership of Polish representative partners in European social partners organizations may be summarized as follows: organizations representing employers - Związek Rzemiosła Polskiego (ZRP) (the Polish Craft Association) is a member of the European Union of Craft, Small and Medium-Sized Enterprises (UEAPME), Polska Konfederacja Pracodawców Prywatnych "Lewiatan" (the Polish Confederation of Private Employers "Lewiatan") - BUSINESSEUROPE, Konfederacja Pracodawców Polskich (the Confederation of Polish Employers) - the European Centre of Enterprises with Public Participation (CEEP); organizations representing employees: NSZZ Solidarność (the Independent and Self-Governing Trade Union NSZZ Solidarność) is a member of the European Trade Union Conferderation (ETUC) and EUROCADRES, (Ogólnopolskie Porozumienie Związków Zawodowych (OPZZ) (the All-Poland Alliance of Trade Unions) is a member of European Trade Union Confederation (ETUC), and a member of FZZ (the Trade Unions Forum) - Związek Zawodowy Kadra ("Kadra" Trade Union) is a member of Confédération européenne des cadres (CEC).

Other types of reform arise by virtue of the emergence of totally new forms of workers' participation, unknown to Polish labour law until the moment at which Poland acceded to the European Union. The appearance of new structures refers mostly to the participation of employees' representations in economic organizations possessing a supranational dimension or in structures whose scope of operations includes two or more Member States. Enabling employees both formal and practical access to information, and consultation regarding matters concerning employment and the workplace, not only imposed new forms of employee representation but in some cases placed staff members at the level of decision making (managerial) centres of trans-Union economic organizations.

57 Supra note 55. 
The European Commission is committed to supporting social partners to ensure effective implementation of social agreements at a national level. Good information and follow-up mechanisms are crucial to the effectiveness of the implementation of agreements ${ }^{58}$. Therefore, it may be assumed that the need for effective participation and the genuine influence of employees on the operations of enterprises at which they are employed resulted in the development of four models of working representation under the Polish labour law system, namely: trade union participation, enterprise (staff) participation, professional participation and the model of employees' participation within an enterprise's management or supervisory bodies ${ }^{59}$. The enterprise participation model is performed by the Act resulting from the implementation of EU Directive 94/4560 in which the rights of workers' representation in particular in so-called multinational enterprises have been determined ${ }^{61}$, namely the Act on European works councils ${ }^{62}$. In this case the model proposed by EU law has been accepted by reason of the nature of the employer and the territorial

58 A.C. Neal, European labour law and social policy: cases and materials, Volume 1, Kluwer Law International, The Hague 2002, at p. 80.

59 J. Stelina, Zbiorowa reprezentacja pracowników w Polsce - stan obecny i perspektywy rozwoju, [in:] 'Problemy kodyfikacji prawa pracy. Wybrane zagadnienia zabezpieczenia społecznego. Referaty na XVI Zjazd Katedr oraz Zakładów Prawa Pracy i Ubezpieczeń Społecznych, Gdańsk 19-21 września 2007', Gdańsk 2007, at p. 90 et seq.

60 Council Directive 94/45/EC of 22 September 1994 on the establishment of a European Works Council or a procedure in Community-scale undertakings and Community-scale groups undertakings for the purposes of informing and consulting employees, O. J. 30.9.1994, L 254, at p. 64 replaced by Directive 2009/38/EC of the European Parliament and of the Council of 6 May 2009 on the establishment of a European Works Council or a procedure in Community-scale undertakings and Community-scale groups of undertakings for the purposes of informing and consulting employees (Recast) (Text with EEA relevance), O. J. 16.5.2009, L 122, at p. 28.

61 Citation after J. Wratny, Niezwiązkowe przedstawicielstwa pracowników w prawie polskim. Stan obecny i perspektywy zmian, [in:] Z. Góral (ed.), 'Z zagadnień współczesnego prawa pracy - Księga jubileuszowa Profesora Henryka Lewandowskiego', Warszawa 2009, at pp. 233-247; J. Wratny, Problemy prawne funkcjonowania w Polsce pozazwiązowych przedstawicielstw pracowniczych, [in:] S. Golimowska, J. Wilkin, M. Bednarski, U. Sztanderska, M.W. Socha, B. Balcerzak-Paradowska (eds.), 'Więzi społeczne i przemiany gospodarcze. Polska i inne kraje europejskie', Warszawa 2009, at pp. 137-150.

62 Act on European work councils of 5 April 2002, Polish O. J. 2002, No. 62, heading 556. 
range of its enterprise's operations. However, a form of enterprise representation securing rights of staff at within enterprises that do not possess characteristics of an EU-scale economic organisation, competitive to trade unions, has been adopted with some reluctance. Finally, an Act on informing and consulting employees ${ }^{63}$ has been adopted. In accordance with the provisions of this Act works councils are appointed at enterprises conducting economic activity and employ at least 50 employees.

Entirely different models of representation have been promoted at the level of organs within multinational entities operating as capital companies and cooperatives. The distinctive characteristic thereof is the employees' right to delegate their representatives to governing bodies (management boards) or supervisory bodies (supervisory boards) of such enterprises. However, the legal authority of the right to delegate representatives is based upon the work (employment) relationship and not upon holding shares or stocks in the relevant enterprise. Nevertheless, some doubts have been raised in the Polish academic literature as to whether delegates appointed under this procedure remain representatives of employees or are representatives of the enterprise itself, by virtue of their participation in the organs of such enterprises ${ }^{64}$. Nevertheless, it should be noted that, upon deeper analysis, the directives de facto provide the double system of working representation in the form of a representative body at an enterprise level and in the form of participation of employees' representatives in management and supervisory bodies of a European Company or European Cooperative Society ${ }^{65}$. The following statutory acts implemented into the Polish legal order the representation form covering participation of employees in management and supervisory bodies of an enterprise: the Act on European Economic Interest Grouping and European Company ${ }^{66}$,

63 Act on informing and consulting employees of 7 April 2006, Polish O. J., No. 79, heading 550.

64 J. Stelina, op. cit., at pp. 91-93; See also M. Seweryński: Załoga zakładu pracy - uwagi de lege ferenda, [in:] 'Reprezentacja praw i interesów pracowniczych (ogólna charakterystyka)', Torun 2001, at p. 50.

65 J. Wratny, op. cit., p. 233.

66 Act on European economic interest grouping and European Company of 4 March 2005, Polish O. J. 2005, No. 62, heading 51. 
the Act on European Cooperative Society ${ }^{67}$, the Act on participation of employees in a company established as a result of cross-border mergers of companies ${ }^{68}$. However, their practical importance is limited, since no cross-national economic entities, the scope of operation of which exceeds the territory of one Member State, have registered offices in Poland.

\section{Conclusion}

Successful integration is the ultimate test of effectiveness of the EU free movement policy ${ }^{69}$ and European labour law. More effective application of European law depends upon the proper transposition of directives and the exercise of effective control over this process. The European Commission gathers implementation reports that play a key role in the analysis of the conformity of national implementation measures. These reports provide a clear picture of the situation in each Member State and provide for the initiation of infringement proceedings where necessary ${ }^{70}$. The principle of effectiveness requires that Member States authorities ensure that Union legislation is fully enforced through appropriate systems of control or sanctions, which are effective in practice $^{71}$. Differences in effectiveness and accessibility of the procedure are noticeable between different Member States. Such differences could, by themselves, render a referral to a foreign court in violation of Article 6 of the European Convention of Human Rights but to date no case law exists to support this proposition ${ }^{72}$. The European Commission has resolved to insert in all future legislation a standard clause that will

67 Act on European Cooperative Society of 22 July 2006, Polish O. J., No. 149, heading 1077.

68 Act on participation of employees in a company established as a result of cross-border mergers of companies of 25 April 2008, Polish O. J. 2008, No. 86, heading 525.

69 A.C. Neal, op. cit., p. 190.

70 Supra, at p. 240.

71 Supra, at p. 241.

72 F. Pennings, Y. Konijn, A. Veldman, Social responsibility in labour relations: European and comparative perspectives, Kluwer Law International, Alphen en Den Rijn 2008, at p. 161. 
establish an obligation for Member States to impose sanctions that are effective, proportionate and dissuasive ${ }^{73}$.

A legal consequence of the principle of effectiveness, as discussed above, is not only a single action performed by the principal national authorities competent for legislation. It is considered as a long changes process to change the national legal order, aiming to ensure the formal and practical implementation of European Union legislation. Poland has taken the action to implement EU law. Various reforms have led to significant changes in Polish labour law and in the competences and organization of the state authorities' apparatus. Such reform has also influenced their legal status. Important changes resulting from the need to abide by EU obligations, both formally and practically, have also affected social partners. This has led to the emergence of totally new forms of workers' participation, unknown to Polish labour law until the moment of Poland's accession to the European Union. Whilst this amounts to proper implementation of worker protection standards, much remains to be achieved and a lack of effectiveness if especially perceptible where the social costs of implementing EU obligations are high, e. g. working time, collective redundancies employees in the event of Gdynia and Szczecin Shipyard.

73 A.C. Neal, op. cit., at p. 241. 